\title{
Involving American Schools in Enhancing Children's Digital Literacy and Raising Awareness of Risks Associated with Internet Usage
}

\author{
Mohammed Tawfik Hussein ${ }^{1}$ \\ Department of Accounting, Finance and Management \\ Information Systems \\ Prairie View A and M University, Prairie View \\ Texas, United States
}

\author{
Reem M. Hussein ${ }^{2}$ \\ Seventh Grade Teacher and Grade Level Administrator \\ International Leadership of Texas-CS \\ College Station \\ Texas, United States
}

\begin{abstract}
The purpose of this study is to shine the light on the importance of educating students on digital literacy and netiquette, for technology has become a common denominator in most of our tasks. This study is mostly concerned with involving schools in educating students on this matter since students spend most of their time in schools. The paper expresses the urgency of increasing the dose of digital literacy taught in schools to help raise students' awareness to potential risks the internet has. It breaks down the risks that young users are prone to face as well as ways to safely avoid them. Further, the paper analyzes the state standards practiced in the US. to serve as a wake-up call for schools to work on improving their standards to protect young users from the versatile harms. Therefore, schools are conjured to take on the role of enhancing students' digital literacy and their understanding of the potential risks present online.
\end{abstract}

Keywords-Digital literacy; e-learning; internet risks; online education and safety

\section{INTRODUCTION}

With every decade and every century of time comes unique trends that capture the interest and curiosity of the generation living within that time frame. The trends peculiar to those ages tend to be relevant to the people and thus it occupies most of their daily tasks by default. With the arrival of the 21st century, the most common phenomenon that spread across the world was technology and its various functionalities that mostly includes the internet. The rapid spread of the internet and technology caused drastic changes in the World that made such an epidemic become the peak of interest for researchers. However, less research has been executed on the ramifications of technology and internet surfing etiquette (netiquette) especially for children of all ages. Novice internet users and technology holders, such as students at schools, can be prone to many of the dangers that technology carries within its folds [1]. Therefore, this paper will firstly shine the light on the literature that covers issues related to technological effects on minors. Also, this paper will discuss the risks that students are bound to face as well as methods to possibly minimize students' risks and enable them to surf the internet safely and more responsibly. This research paper is organized as follows: Section II presents the literature search and review used; Section III gives the definition of what is the digital literacy; Section IV covers the importance of teaching student's digital literacy and online safety measures while Section V covers the potential 21st century risks facing young internet users; and Section VI deals with how schools contribute effectively to minimizing students' online risks. In Section VII, conclusion and contributions are discussed, and finally future work is discussed in Section VIII.

\section{LITERATURE REVIEW}

The Worldwide proliferation of technology that initially started as a trend, is becoming a norm and a must in almost all organizations and for all its users. The internet, specifically, is found to be very effective in many realms, especially in the realm of education [2]. The technological advances are attracting more school boards across the world to adopt its many resources into its curriculum [3]. Consequently, 21stcentury education is now majorly defined by students' digital use throughout their school years, and many of its tools are holistically reliant on the internet [4].

With its rapid spread and development, children are easily gaining access to many of its forms at home, at school, and at other different locations [5], which is raising many concerns among scholars. The product so-called "internet" is granting minors access to its many constituents almost for free but without a manual of instructions or precautions that they should take while surfing the web [6]. The dearth of studies concerned with raising awareness on internet safety measures is causing an imbalance leading to children's exposure to many risks without a shield to protect them [7].

While the internet is massively used as an entertaining outlet or an educational media, others use it to target vulnerable users in ways to bully them, mislead them with wrong data, hurt them, or sexually harass them. Unfortunately, these phenomena are part of the package when becoming an internet user and it's widely spreading to where it's part of the internet's culture [8]. Children's scarce knowledge concerning digital literacy is allowing child predators and other adversaries to use these gaps in ways that harm children without them knowing.

According to a learning.com study, among 110,000 students in America who took the learning.com survey, more than \%75 of fifth and eighth graders are not equipped with the 
proper tools to use the internet safely [9]. Without the right preparations, students are prone to fall into the many black holes that are woven into the internet system.

Therefore, the urge to teach students of all ages about online safety measures simultaneously while using the internet is imperative [10]. The author in [11] suggested that schools and parents need to cooperate in an effort to minimize students' exposure to online risks as well as to increase their digital knowledge so they can become vigilant users.

\section{WHAT IS DigITAL LITERACY}

The term 'digital' encompasses computers, the internet, cell phones and any form of technology used nowadays. Becoming digitally literate means to harness all necessary skills that allows the user to carefully navigate through the internet, respect authorship rules, understand social responsibility and netiquette, and react professionally to any attempts of bullying or harm [12].

\section{THE IMPORTANCE OF TEACGINH STUDENTS DigITAL LITERACY AND ONLINE SAFETY MEASURES}

Due to the continuous advances in technology, new names to describe this era are being created. "In 1998, Don Tapscott talked about the 'Net Generation', in 2001 Marc Prensky coined the term 'digital natives'.” [13]. Students' preferences for how they want to learn and preform their daily tasks are redefined and are majorly dependent on technology [5].

The escalating digital use is becoming a norm that requires a high level of understanding and literacy to avoid potential risks. Adversaries are using the unlimited online potential to target those who are digitally illiterate via different outlets including virus infected websites, social media sites, website scams and false advertising, sexual exposing contents, and selfharm-oriented websites.

Studies have shown that the possibility of children staying out of the internet's risks is by having parent, school, and peer supervision. However, The EU Kids Online survey shows that half of children's access is from private places, including their bedrooms, where supervision is not available which makes them prone to many risks [14]. Therefore, the urge to have students educated on digital literacy is highly needed since they are not always surrounded with those who will supervise and protect them. The more children are equipped with the right knowledge to work out any problems or obstacles they may face online, the less others will need to step in to protect them while online.

Furthermore, the 21st century curriculum is based on teaching student's college preparatory skills that involves technology-based tasks. If children were taught the proper ways to use technology and utilize it for beneficial causes, they will grow professionally and become strong candidates for future jobs that are predicted to be holistically reliant on technology [15]. Hence, the crucial role of schools in promoting digitally literate generations [5].

\section{Potential $21^{\text {ST }}$ CEnTURY Risks FACing Young INTERNET USERS}

While the internet exudes many positive traits and benefits, it is also a medium used for many dangerous acts that are set by many parties including hackers, bullies, pedophiles, selfharm advocates, and thieves. The arising threats against young users, specifically, are raising parents' concerns towards their children's exposure to the internet [8].

Among the problems that children are expected to stumble upon is meeting strangers. Some predators use social media and other forms of online communications to trick children into sending pictures, sharing personal information, or arranging meetings [16]. Children can also be exposed to sexual content accidentally or deliberately. As part of the unlimited internet access and the limited policies and rules controlling the giant web, students are most likely to bump into inappropriate and explicit advertisements when surfing untrusted or unprofessional sites.

Furthermore, children who have at least one social media account is prone to cyberbullying [17], which is becoming an alarming epidemic [18]. Students at a young age are still building their personalities and are trying to discover their interests and talents, which puts them in a sensitive stage to where negative comments become vital to their health and selfesteem [19]. In fact, the term cyber bullying developed as a result of adolescents (ages 12-18) profoundly using the social network to negatively shame, embarrass, and break their peer's confidence, and thus ostracize them from their social groups [19].

Moreover, the ubiquitous use of websites is creating a pathway for adversaries to spread phishing threats and hidden computer viruses through websites that are familiar to the user. Those threats tend to be among the most dangerous methods used to obtain personal information as it looks very similar to legitimate websites, applications, and emails [20], without the right training on this issue, children can easily fall into the nets of fraudsters without knowing [21].

Additionally, according to the EU Kids online survey [2223], among the top activities that children use the internet for is playing games and watching video clips [13], which is also the same methods self- harm advocates use to encourage suicide and other deviant acts. The recent challenge known as the "Momo challenge", which features a female Japanese sculpture with giant eyes and a sharp grin, has been spreading around among children via social media asking children to hurt and kill themselves [24]. Earlier in the year, rumors of a similar game familiar as the 'Blue Whale Challenge' took place in different countries asking students to also harm themselves and execute 50 harming challenges within a period of 50 days [25]. Such games were built on concepts of competitivity, peer pressure and the lack of adult supervision. The key to not get sucked in these games is by being digitally literate enough to know that these games are threats and another form of cyber bullying, that needs to be reported immediately [26]. 


\section{HOW CAN SCHOOLS CONTRIBUTE EFFECTIVELY IN MiNIMIZING STUDENTS’ ONLINE RISKS}

According to the National Center on Education and the Economy (NCEE), the average time spent in schools across countries is around 175 to 220 days with an average of 6.8 hours spent daily [27]. These numbers show that students spend a great amount of time in schools every year, which can be very imperative and fundamental to their growth if they are given the right knowledge. Thus, the numerous hours spent in schools play a role in increasing the trust levels between teachers and students. Based on the EU Kids Online Survey [28], when Australian children are bothered by something online, they are most likely to turn to a teacher or a parent for help. Even though this study mostly specifies Australian kids, it is very common for students to address teachers when needing help, especially those they trust [29]. Therefore, teachers' effects on the issue of preventing online risks are imperative and schools should use its platform to raise awareness on the former online risks.

Firstly, schools are encouraged to organize multiple student seminars that addresses online risks and ways to gain immunity against such harms. These seminars will help serve as reminders for students as well as it will keep them up to date with the skyrocketing development of technology and its many flaws and risks.

The technology standards that are practiced in the states following the common core mostly revolves around students' literacy on formulas, functions, spreadsheet knowledge, presentation creation, importing data and exporting data, problem solving specific to technology tools, keyboarding, typing, toolbar functions, plagiarism, and personal data sharing [30]. On the contrary, the common core technology standards briefly focus on the many forms of cyber bullying and how social media is playing a major role in that. It also didn't mention anything about the phishing phenomenon, computer viruses, online pedophiles and websites that seek the attainment of personal information. While it is crucial for students to know about the computers' many functions and benefits, it is also important for them to know about the risks they are highly expected to encounter while using the computer.

While forty-one states adopted the former technological standards, the other nine states left and developed their own standards including technology related standards. After examining each of the nine states' recently adopted standards for the 2019-2020 school year, that are specific to technology, it was found that Oklahoma and Alaska did not mention the 21st century risks talked about above (cyberbullying, phishing scams, virus-based risks, self-harm invoking games and videos, or online offenders...etc.) Rather, its major focus was mainly on proper computer and internet usage through utilizing its hardware and software tools correctly to problem solve and execute research projects successfully. Indiana, and Virginia; however, talked about the major computer rules as well as slightly mentioning the dangers of cyberbullying. The 3-5 grade technology standards found in the Texas Essential Knowledge Standards (TEKS) did not have strands focusing on the 21st century risks, whereas the 6-8 technology TEKS did.
According to the TEA website, the technology TEKS briefly talked about cyber bullying and virus-related risks as most of its strands were dedicated more towards computer usage, keyboarding, and its related tools. Similarly, to the technology TEKS in Texas, Indiana's standards were also brief on cyberbullying while the bulk of its standards focused on functionality and utilization of the internet and the computer. South Carolina and Florida were the only states that talked about three or more of the potential 21st century risks including cyberbullying, phishing, and virus-related risks. The only state that did not have standards specific to technology on its website was Nebraska [31-40], which could either mean that technology might not be a top priority subject or that it might be part of another subject's standards instead of its own.

From the previous information, it can be concluded that technology as a subject is not among the schools' priorities as it's not part of the standardized testing process compared to math, English and science [41], [42]. Despite its insignificance, most of the schools in America have technology standards that address basic knowledge on the use and functionality of advanced devices, such as computers and cell phones, and the internet. The deficiency found in those standards; nonetheless, was that they either lightly focused on the 21st century online risks (cyberbullying, phishing scams, virus-related risks, offenders...etc.) or they did not mention them at all.

Therefore, schools in America are implored to maximize the attention on digital literacy specifically literacy related to the spreading risks of the 21st century. Even though children are not tested on technology, they are highly in need of guidance that teaches them how to roam the internet safely as part of the default trend of owning a device and having access to the internet.

Since schools in America are truly dedicated to preparing students for the future and for real life situations, then they ought to dedicate more time in teaching students technology literacy skills and netiquette because that is the future [43]. Since students as young as seven years old are owning phones nowadays [44], digital literacy and online risks awareness lessons should be boosted in schools from kindergarten all the way to high school.

\section{CONCLUSIONS}

The 21st century brought the world a double-edged component that is quickly growing to become among the most fundamental components of life. Technology might have not been that important because it was not so widespread as it is currently [45]. The evolving technology that involves the internet, is bringing its users insurmountable benefits as well as potential harm if the user was not vigilant and digitally literate. This paper mostly focuses on young users who are not literate enough to surf the internet freely, yet they do. [23]. Parents normally would supervise their children to make sure they are using the internet safely; however, parents are not always present everywhere the child goes [23]. Children tend to surf the internet in private places where supervision is not present, which can be risky if they are not familiar with potential 21st century risks. Therefore, schools are conjured to take on the role of enhancing students' digital literacy and their understanding of the potential risks present online. In fact, even 
though technology is not part of standardized tests, it is among the few skills that students will remember and use in the real world. It is an undeniable fact that technology is becoming part of every institution, organization, restaurant, entertainment place, and home. The importance of intensifying students' dose of digital literacy in schools is discussed and explained as an urgent issue requiring awareness, which achieves the stated objective for this study. A review of the literature reveals an alarming lack of attention to the prevalent threat of lowtechnology, or low-complexity phishing attacks. Accordingly, here is a primer on the prominent exploit known as phishing, illustration of several cases, and the necessity for organizational and societal education of data users as to appropriate computer hygiene [46].

The unintended consequences facing humans as they attempt to govern the process of artificial intelligence, machine learning, and the impact of billions of sensory devices connected to the Internet is a challenge to all involved [47].

\section{FUTURE WORK}

As future work, the authors will select a school for a pilot study to conduct training for teachers and raise technology awareness for students as well as test their readiness for minimizing the risk associated with internet usage and compare it with the other schools that did not get same training and awareness.

\section{ACKNOWLEDGMENT}

The authors would like to thank the College of Business at Prairie View A\&M University and International Leadership of Texas for the support and providing the healthy environment to conduct and execute this research.

\section{REFERENCES}

[1] Dias, P., Gomes M.J., \& Correia, A. P., Disorientation in hypermedia environments: Mechanisms to support navigation. Journal of Educational Computing Research, 20(2), 93-117, 1999.

[2] Liaw, S. S., Information technology and education: Student perceptions of computer and web-based environments. Doctoral dissertation, Seattle Pacific University, 2000.

[3] Trucano, M., A new research hub on the use of technology in education in developing countries. Edutech. Retrieved from https://blogs.worldbank.org/edutech/new-research-hub-use-technologyeducation-developing-countries, 2019.

[4] Pavlova, M., Roebuck, D., Learning in technology education challenges for the 21st century. Griffith University. Retrieved from https://pdfs.semanticscholar.org/408f/892cc5a8ee1c4fcd1470bda2e520b 197a0ee.pdf, 2002.

[5] Livingstone, S., Haddon, L., \& Anke, G. (Eds.), Children, risk and safety on the internet Research and policy challenges in comparative perspective. Retrieved from http://ebookcentral.proquest.com, 2012.

[6] Aggarwal, S., Breeden, B., Henry., P., Mulholland, J., in International Federation for information processing. Advances in Digital Forensics Il, eds. Olivier, M.. Shenoi, S., (Boston: Springer). pp. 317-330, 2006.

[7] Valcke, M., Schellens, T., Van Keerand, H., \& Gerarts, M., Primary school children's safe and unsafe use of the Internet at home and at school: An exploratory study. Computers in Human Behavior, 23(6), 2838-2850, 2007.

[8] Finkelhor, D. (2011). The internet, youth and the problem of "juvenoia". Crimes against children research center. Retrieved from http://unh.edu/ccrc/pdf/Juvenoia\%20paper.pdf, 2011.

[9] Blackwell, H. (2017). More than 75 percent of fifth and eighth graders are non-proficient in 21st century skills, according to learning. com study. Learning.com. Retrieved from https://www.learning.com/pressreleases/75-percent-fifth-eighth-graders-non-proficient-21st-centuryskills-according-learning-com-study, 2017.

[10] Anastasiades,P.\& Vitalaki, E., Promoting internet safety in Greek primary schools: the Teacher's Role. Educational Technology \&Society, 14(2), 71-80, 2011.

[11] Dombrowski, S. \& Gischlar, K., Keeping children safe on the internet: Guidelines for parents. National Association of school psychologists. Retrieved from file:///C:/Users/reemh/Downloads/Keeping_Children_ Safe_on_the_Internet_Gu.pdf, 2007.

[12] Loveless, B., The importance of digital literacy in K-12. Education Corner. Retrieved from https://www.educationcorner.com/importancedigital-literacy-k-12.html, 2019.

[13] Sonck, N., Kuiper, E., De Haan, J., Digital skills in the context of media literacy: From Livingstone, S., Haddon, L., \& Anke, G. (Eds.), Children, risk and safety on the internet, 2012.

[14] Helsper, E., Which children are fully online?: from the Livingstone, S., Haddon, L., \& Anke, G. (Eds.), Children, risk and safety on the internet : Research and policy challenges in comparative perspective. Retrieved from http://ebookcentral.proquest.com, 2012.

[15] Roteman, D., How technology is destroying jobs. MIT technology review. Retrieved from https://www.technologyreview.com/s/515926/ how-technology-is-destroying-jobs/, 2013.

[16] Aggarwal, S., Breeden, B., Henry., P., Mulholland, J., in International Federation for information processing. Advances in Digital Forensics Il, eds. Olivier, M.. Shenoi, S., (Boston: Springer). pp. 317-330, 2006.

[17] Lampert, C., \& Donoso, V., Bullying: from the Livingstone, S., Haddon, L., \& Anke, G. (Eds.). (2012). Children, risk and safety on the internet : Research and policy challenges in comparative perspective. Retrieved from http://ebookcentral.proquest.com, 2012.

[18] Valeeva, R., Ribakova, L., Bullying in schools: Case study of prevention and pshycho-pedagogical correction. International journal of environment \& science education. 11(7), 1603-1617, 2016.

[19] Kane, G. (2013). Psychosocial stages of symbolic action in social media. Thirty fourth international conference on information systems. Retrieved from https://pdfs.semanticscholar.org/7afd/4e6a10850f1d012e783db73 791d1bcbccd06.pd, 2013.

[20] Boulton, J., Boulton, L., Camerone, E., Down, J., Hughes, J., Kirkbirde, C., Kirkham, R., Macaulay, P., \& Sanders, J., Enhancing primary school children's knowledge of online and risks with the CATZ cooperative cross-age teaching intervention: Results from a pilot study. Cyberpsychology, behavior, and social networking, 19 (10). Retrieved from https://www.ncbi.nlm.nih.gov/pubmed/27732078, 2016.

[21] Last Dräger, E., Gallardo, I., Hartel, P., \& Junger, M., How effective is anti-phishing training for children. Usenix association. Retrieved from https://www.usenix.org/system/files/conference/soups2017/soups2017lastdrager.pdf, 2017.

[22] Haddon, L., Görzig, A., and Ólafsson, K. (2011). Risks and safety on the internet: The perspective of European children. Full Findings. LSE, London: EU Kids Online, 2011.

[23] Green, L., Brady, D., Olafsson, K., Hartley, J., \& Lumby, C. A., Risks and safety for Australian children on the internet: full findings from the AU Kids Online survey of 9-16 year olds and their parents. Retrived from https://researchers.mq.edu.au/en/publications/risks-and-safety-foraustralian-children-on-the-internet-full-fin, 2011.

[24] Davidson, T. (2018). Momo 'suicide challenge': Deaths of boy, 16, and girl, 12, linked to sick WhatsApp game. Mirror. Retrieved from https://www.mirror.co.uk/news/world-news/momo-suicide-challengedeaths-boy-13185367, 2018.

[25] Rossow, A., Cyberbullying taken to a whole new level: Enter the 'blue whale challenge'. Forbes. Retrieved from https://www.forbes.com/ sites/andrewrossow/2018/02/28/cyberbullying-taken-to-a-whole-newlevel-enter-the-blue-whale-challenge/\#c143c6d2673e, 2018.

[26] Polizzi,G., The blue whale game paradox, digital literacy and fake news. Parenting for a digital future. Retrieved from http://eprints.lse.ac.uk/ 79151/1/Parenting\%20for\%20a\%20Digital\%20Future\%20\%E2\%80\%93 \%20The\%20Blue\%20Whale\%20game\%20paradox\%2C\%20digital\%201 iteracy\%20and\%20fake\%20news.pdf, 2017. 
[27] Craw, J., Statistics of the month: How much time do students spend in school? National Center on education and the economy. Retrieved from http://ncee.org/2018/02/statistic-of-the-month-how-much-time-dostudents-spend-in-school/. 2019.

[28] Research and policy challenges in comparative perspective. Retrieved from http://ebookcentral.proquest.com

[29] Da Luz, Fredson Soares dos Reis, The Relationship between Teachers and Students in the Classroom: Communicative Language Teaching Approach and Cooperative Learning Strategy to Improve Learning. Retrieved from https://vc.bridgew.edu/theses/22, 2015.

[30] Common core state standards K-12 technology skills scope and sequence. (n.d.). Retrieved from https://www.fresnounified.org/dept/ curr/tech/PublishingImages/K12_Technology_Scope_and_Sequence.pdf , 2007.

[31] Computer standards of learning for Virginia's public schools. Retrieved from http://www.doe.virginia.gov/testing/sol/standards_docs/computer_ technology/2012/stds_comptech_6-8.pdf. 2013.

[32] Florida computer science standards, Retrieved from http://www.cpalms.org/Uploads/docs/Standards/computerscience/Scienc e_ComputerScience_Standards.pdf, 2016.

[33] Indiana department of education: Computer science resources. (2018). Retrieved from https://www.doe.in.gov/standards/computer-scienceresources-6-8, 2018.

[34] Indiana department of education. Retrieved from https://www.doe.in.gov /standards/computer-science-resources-3-5, 2018.

[35] Indiana k-12 computer science standards. (n.d.). Retrieved from https://www.doe.in.gov/sites/default/files/wf-stem/ind-k-12-computerscience-standards.pdf.

[36] Oklahoma state department of education. (n.d.). Retrieved from https://sde.ok.gov/sites/ok.gov.sde/files/C3\%20PASS\%20gr6_10teched. pdf.

[37] South Carolina computer science and digital literacy standards. Retrieved from https:/ed.sc.gov/scdoe/assets/File/instruction/standards/ Computer\%20Science/FINAL_South_Carolina_Computer_Science_and _Digital_Literacy_Standards_(SBEApproved050917)063017.pdf, 2017.
[38] Texas Essential Knowledge and Skills. Retrieved from file://C:/Users/reemh/Downloads/TA_Grades\%203-5_1110\%20(3).pdf, 2010.

[39] University of Alaska Fairbanks. (n.d). Retrieved from https://www.uaf.edu/files/soe/Elementary/AK-Content-Standards.pdf

[40] Nebraska department of education. Retrieved from https://www.education.ne.gov/contentareastandards/, 2019.

[41] Bochniak, V., Schools fall flat of preparing. students for the future. The clark chronicle. Retrieved from https://clarkchronicle.com/opinion/ 2018/05/22/schools-fall-flat-of-preparing-students-for-the-future/, 2018.

[42] David, L., Research says high stakes testing narrows the curriculum. Educational leadership 68(6). Retrieved from http://www.ascd.org/publications/educational_leadership/mar11/vol68/n um06/High-Stakes_Testing_Narrows_the_Curriculum.aspx, 2011.

[43] Cantor, D., Struggle for the future: Schools lag in preparing students for the age of automation. The 74. Retrieved from https://www.the74million.org/article/struggle-for-the-future-schools-lagin-preparing-students-for-the-age-of-automation/, 2018.

[44] Chen, B., What's the right age for a child to get a smartphone? The New York Times. Retrieved from https://www.nytimes.com/2016/07/21 /technology/personaltech/whats-the-right-age-to-give-a-child-asmartphone.html, 2016.

[45] Leask, A., Student then students now: What's changed? Enable education. Retrieved from http://enableeducation.com/student-then-andstudent-now-whats-changed/, 2013.

[46] Trautman, Lawrence J. and Hussein, Mohammed and Opara, Emmanuel U. and Molesky, Mason and Rahman, Shahedur, Posted: No Phishing Emory Corporate Governance and Accountability Review (2021), Available at SSRN: https://ssrn.com/abstract=3549992 or http://dx. doi.org/10.2139/ssrn.3549992, (March 6, 2020).

[47] Trautman, L. J., Hussein, M. T., Ngamassi, L., \& Molesky, M. J. Governance of the Internet of Things (IoT), Jurimetrics, Vol. 60, Issue No. 3, (Spring 2020). 